\title{
Different apoptotic mechanisms are involved in the antiproliferative effects of $7 \beta$-hydroxysitosterol and $7 \beta$-hydroxycholesterol in human colon cancer cells
}

\author{
S Roussi ${ }^{1}$, A Winter ${ }^{1}, F_{\text {Gosse }}{ }^{1}$, D Werner ${ }^{2}$, X Zhang $^{3}$, \\ E Marchioni ${ }^{3}, \mathrm{P}$ Geoffroy ${ }^{4}$, M Miesch $^{4}$ and F Raul ${ }^{*, 1}$ \\ 1 Laboratoire d'Oncologie Nutritionnelle, Inserm UMR S392/IRCAD, 1, place de \\ l'Hôpital, BP 406, Strasbourg Cedex 67091, France \\ ${ }^{2}$ Aérial, 19 rue de Saint Junien, Schiltigheim F-67300, France \\ ${ }^{3}$ Laboratoire de Chimie Analytique et Sciences de l'Aliment, ULP/CNRS UMR \\ 7512, Faculté de pharmacie, 74, route du Rhin, Illkirch 67400, France \\ ${ }^{4}$ Laboratoire de Chimie Organique Synthétique, ULP/CNRSUMR 7123, 1, rue \\ Blaise Pascal, Strasbourg-Cedex 67008, France \\ * Corresponding author: F Raul, Laboratoire d'Oncologie Nutritionnelle, Inserm \\ UMR S392/IRCAD, 1, place de l'Hôpital, BP 406, Strasbourg Cedex 67091, \\ France. Tel.: + 33-3-88-11-90-23; Fax: + 33-3-88-11-90-97; \\ E-mail: francis.raul@ircad.u-strasbg.fr
}

Received 04.8.04; revised 04.10.04; published online 19.11.04 Edited by RA Knight

\begin{abstract}
Plant sterols are found in fruits and vegetables. Their cholesterol-lowering effect is well documented. Our study aimed at comparing antiproliferative effects of $7 \beta$-hydroxysitosterol (7 $\beta$-OHsito) versus $7 \beta$-hydroxycholesterol $(7 \beta$-OHchol) on the human colon cancer cell line Caco-2. When cells were exposed for $32 \mathrm{~h}$ to $60 \mu \mathrm{M} 7 \beta$-OHsito or to $30 \mu \mathrm{M} 7 \beta-\mathrm{OHchol}$, both compounds caused $50 \%$ growth inhibition. Cells treated with $7 \beta$-OHsito showed enhanced caspase-9 and -3 activities followed by DNA fragmentation. In contrast, $7 \beta-\mathrm{OH}$ chol did not activate caspase-3 and activation of caspase- 9 and DNA fragmentation were delayed. The treatment of cells with the caspase inhibitor Z-VAD.fmk retarded the $7 \beta$-OHsito-induced apoptotic process but not that triggered by $7 \beta-\mathrm{OHchol}$. Our data suggest that the two compounds in spite of their structural similarities target different cellular pathways, which lead to cell death.

Cell Death and Differentiation (2005) 12, 128-135.

doi:10.1038/sj.cdd. 4401530

Published online 19 November 2004
\end{abstract}

Keywords: apoptosis; Caco-2 cells; $7 \beta$-hydroxysitosterol; $7 \beta$-hydroxycholesterol; caspases; cholesterol metabolism

Abbreviations: $7 \beta$-OHchol, $7 \beta$-hydroxycholesterol; $7 \beta$-Ohsito, $7 \beta$-hydroxy sitosterol; PI, propidium iodide; HMG-CoA reductase, 3-hydroxy-methylglutaryl coenzyme A reductase; DMSO, dimethyl sulfoxide

\section{Introduction}

Plant sterols are abundant in vegetables and fruits. Among the phytosterols, sitosterol, campesterol and stigmasterol, are the most important. They are structural analogues of cholesterol. Numerous laboratory studies focused on their potential to reduce cholesterol absorption by the small intestine ${ }^{1-4}$ and cholesterol uptake by LDL. ${ }^{5-7}$ In addition, it was reported that phytosterols prevent coronary heart disease, ${ }^{8}$ and cardiovascular risks. ${ }^{9-11}$ However, their potential to reduce the risk of cancer remains controversial. ${ }^{5,12-14}$ Several studies showed antiproliferative properties of plant sterols, on human breast cancer cells, ${ }^{15,16}$ prostate cancer cells, ${ }^{17}$ HT-29 ${ }^{18,19}$ and HCT116 human colon cancer cells. ${ }^{20}$ It was suggested that these effects are related to the activation of the sphingomyelin cycle, to cell cycle arrest and/ or to the stimulation of apoptosis. ${ }^{18,19}$ Induction of apoptosis by $\beta$-sitosterol was mediated by increased levels of the proapoptotic Bax protein and caspase induction. ${ }^{20}$

Phytosterols undergo oxidation during cooking and storage. However, only a few data are available on biological activities of oxyphytosterols. ${ }^{21,22}$ It was reported that they cause cellular damage in cultured macrophage-derived cell lines ${ }^{23}$ and that hydroxysitosterol induces apoptosis of U937 cells, accompanied by a reduction of cellular glutathione. ${ }^{24}$

Furthermore, numerous studies reported atherogenic ${ }^{25,26}$ and cytotoxic properties ${ }^{27-30}$ of cholesterol oxides, leading to apoptosis or necrosis in various cell types. ${ }^{24,31-33}$ They may also exert their effects by lowering cholesterol availability for cell membrane formation by inhibiting 3-hydroxy-methylglutaryl coenzyme $A$ reductase (HMG-CoA reductase), a key enzyme in cholesterol synthesis. ${ }^{34}$ Cholesterol oxides bind to specific membrane receptors or cytosolic binding proteins, leading to the perturbation of cholesterol synthesis. ${ }^{35-37}$ It was also shown that $7 \beta$-hydroxycholesterol $(7 \beta$-OHchol) and 7 -ketocholesterol may initiate nonapoptotic death in U937 cells. ${ }^{38}$ These findings highlight the many biological effects of cholesterol oxides. However, the mechanism by which hydroxyphytosterol and hydroxycholesterol induce cell death remains unknown.

In the present study, we aimed at comparing the antiproliferative properties of $7 \beta$-hydroxysitosterol $(7 \beta-\mathrm{OH}$ sito) and $7 \beta$-OHchol in the Caco-2 human colon cancer cells. Cytotoxicity of $7 \beta-\mathrm{OH}$ chol or other cholesterol oxides have been reported on HT-29 and SW620 human colon cancer cells. ${ }^{39}$ Since $7 \beta$-OHsito and $7 \beta-\mathrm{OH}$ chol are the most abundant hydroxysterols $^{34,40}$ present in food after cooking and storage, it was of interest to compare their cytotoxic effects. In order to determine whether both molecules induced the same or different apoptotic process in cancer cells, we assessed cell viability, cell cycle analysis, caspases activities and DNA fragmentation. Our data show that both compounds are cytotoxic, but that the pathways leading to cell death are different.

\section{Results}

\section{Effects of $7 \beta-\mathrm{OHsito}$ and $7 \beta-\mathrm{OHchol}$ on Caco-2 cell growth}

Growth of Caco-2 cells was determined using the sulforhodamine $B\left(\right.$ SRB) dye method. ${ }^{41}$ As shown in Figure 1, growth 
inhibition was observed when cells were exposed to $7 \beta$ $\mathrm{OHsito}$ and $7 \beta$-OHchol in a dose-dependent manner. Cells were more sensitive to $7 \beta$-OHchol than to $7 \beta$-OHsito (Table 1). A similar number of dead cells was obtained with $60 \mu \mathrm{M}$ $7 \beta$-OHsito than with $30 \mu \mathrm{M} 7 \beta$-OHchol. After $32 \mathrm{~h}$ of treatment, a $50 \%$ cell survival was observed, and all further studies were performed at these concentrations. These compounds are known to induce cell necrosis at higher concentrations. ${ }^{42}$

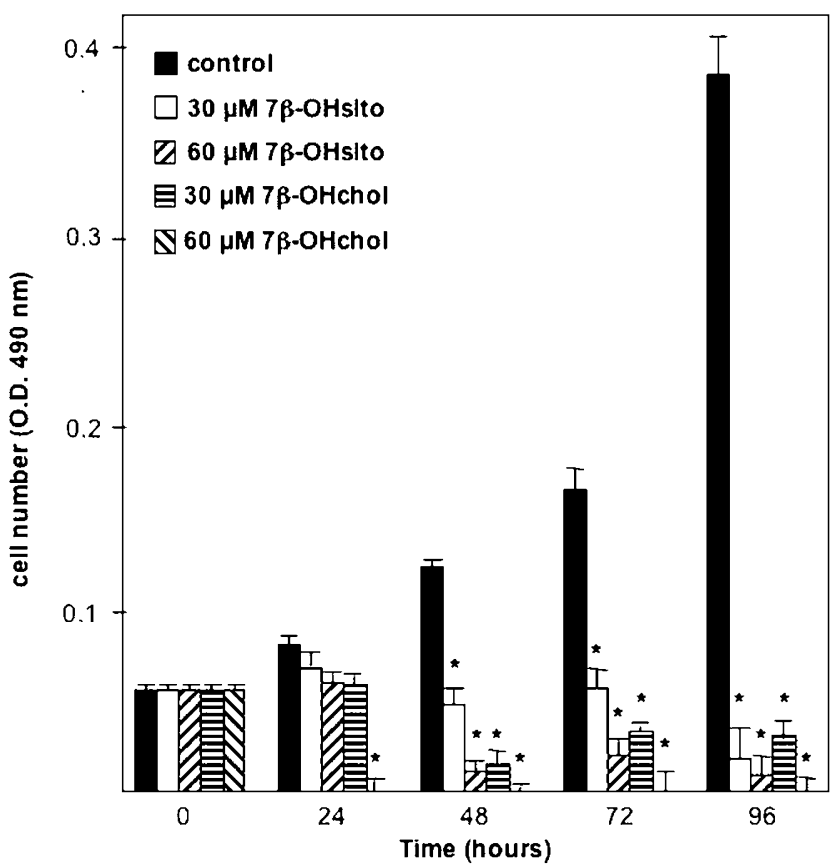

Figure 1 Effects of $7 \beta$-OHsito and $7 \beta-\mathrm{OHchol}$ on Caco-2 cell growth. Cells were exposed to $0.5 \%$ ethanol (control), $7 \beta$-OHsito $(30$ and $60 \mu \mathrm{M})$ and $7 \beta$ OHchol $(30$ and $60 \mu \mathrm{M})$ for $96 \mathrm{~h}$. Data are presented as the mean \pm S.E. of at least three separate experiments. The asterisk indicates a significant difference between controls and treated $(P<0.05)$

\section{$7 \beta$-OHsito and $7 \beta$-OHchol effects on cell cycle}

Exponentially growing Caco-2 cells exposed to both hydroxysterols were analyzed by flow cytometry after staining with propidium iodide $(\mathrm{PI})^{43}$ (Figure 2 ). When compared with nontreated controls, $7 \beta$-OHsito caused after $32 \mathrm{~h}$ a significant accumulation of cells in the $S$ phase. The proportion of cells in the $S$ phase was $60 \%$ at $32 \mathrm{~h}$ and reached $50 \%$ at $48 \mathrm{~h}$. The accumulation of cells treated with $7 \beta-\mathrm{OHchol}$ in the $\mathrm{S}$ phase was delayed reaching a proportion of $43 \%$ at $72 \mathrm{~h}$.

In the case of $7 \beta$-OHsito, the accumulation of cells in the $S$ phase at $48 \mathrm{~h}$ was associated with a simultaneous increase of hypodiploid cells (sub-G0/G1), which may indicate an apoptotic process. ${ }^{42} \mathrm{~A}$ similar number of hypodiploid cells was not observed with $7 \beta-\mathrm{OH}$ chol before $72 \mathrm{~h}$ of treatment.

\section{$7 \beta$-OHsito increases caspase- 3 and -9 levels in Caco-2 cells}

In order to ensure that cell death induced by both hydroxysterols was the result of apoptosis, we used a colorimetric substrate, Ac-DEVD-pNA, which mimics the cleavage site of an endogenous substrate PARP. ${ }^{44}$ In cells exposed to $7 \beta$-OHsito, caspase-3 activity reached a maximum value at $32 \mathrm{~h}$ (Figure 3 ). This was not observed in control cells or in cells treated with $7 \beta$-OHchol.

Several specific substrates were also used in order to investigate whether caspase-8 or -9 were activated after treatment with hydroxysterols. As shown in Figure 4, caspase- 9 activity was significantly enhanced in cells exposed to $7 \beta$-OHsito for $32 \mathrm{~h}$. In contrast, when cells were treated with $7 \beta-\mathrm{OHchol}$, caspase- 9 was activated only after $56 \mathrm{~h}$. Caspase- 8 activity remained at a basal level in cells treated with both hydroxysterols (data not shown). Thus, caspase- 3 and -9 were simultaneously activated in cells treated with $7 \beta$-OHsito, while with $7 \beta$-OHchol, only a retarded and small increase of caspase- 9 activity was observed.

Table 1 Concentration- and time-dependent effect of hydroxysterols on Caco-2 cell death

\begin{tabular}{|c|c|c|c|c|c|}
\hline Time (h) & Cells & Control & $7 \beta$-Ohsito $(60 \mu \mathrm{M})$ & $7 \beta$-Ohchol $(30 \mu \mathrm{M})$ & $(60 \mu \mathrm{M})$ \\
\hline 12 & $\begin{array}{l}\text { Total }\left(\times 10^{5}\right) \\
\text { Dead }(\%)\end{array}$ & $\begin{array}{l}4.1 \pm 0.3 \\
0.0 \pm 0.0\end{array}$ & $\begin{array}{l}4.8 \pm 0.9 \\
2.7 \pm 0.3\end{array}$ & $\begin{array}{l}4.3 \pm 0.9 \\
3.8 \pm 0.5\end{array}$ & $\begin{array}{l}4.4 \pm 0.9 \\
5.9 \pm 0.9\end{array}$ \\
\hline 24 & $\begin{array}{l}\text { Total } \\
\text { Dead }\end{array}$ & $\begin{array}{r}7.0 \pm 0.2 \\
11.1 \pm 2.8\end{array}$ & $\begin{array}{r}4.8 \pm 1.2 \\
32.6 \pm 1.8\end{array}$ & $\begin{array}{r}6.1 \pm 0.1 \\
33.3 \pm 1.3\end{array}$ & $\begin{array}{r}3.1 \pm 0.3 \\
78.2 \pm 4.8\end{array}$ \\
\hline 32 & $\begin{array}{l}\text { Total } \\
\text { Dead }\end{array}$ & $\begin{array}{l}8.3 \pm 1.3 \\
8.5 \pm 1.8\end{array}$ & $\begin{array}{r}6.3 \pm 1.1 \\
54.7 \pm 3.2\end{array}$ & $\begin{array}{r}4.7 \pm 1.0 \\
53.1 \pm 1.3\end{array}$ & $\begin{array}{r}1.8 \pm 0.3 \\
84.3 \pm 5.2\end{array}$ \\
\hline 48 & $\begin{array}{l}\text { Total } \\
\text { Dead }\end{array}$ & $\begin{array}{l}9.5 \pm 1.4 \\
4.8 \pm 4.2\end{array}$ & $\begin{array}{r}3.2 \pm 0.2 \\
73.8 \pm 2.8\end{array}$ & $\begin{array}{r}3.8 \pm 0.5 \\
75.6 \pm 2.5\end{array}$ & $\begin{array}{r}2.2 \pm 0.6 \\
92.8 \pm 7.2\end{array}$ \\
\hline 56 & $\begin{array}{l}\text { Total } \\
\text { Dead }\end{array}$ & $\begin{array}{r}11.2 \pm 2.1 \\
9.9 \pm 2.0\end{array}$ & $\begin{array}{r}3.6 \pm 2.1 \\
81.0 \pm 1.7\end{array}$ & $\begin{array}{r}5.6 \pm 0.3 \\
76.7 \pm 3.3\end{array}$ & $\begin{array}{r}3.3 \pm 0.2 \\
97.9 \pm 2.1\end{array}$ \\
\hline 72 & $\begin{array}{l}\text { Total } \\
\text { Dead }\end{array}$ & $\begin{array}{r}11.9 \pm 0.4 \\
3.7 \pm 3.0\end{array}$ & $\begin{array}{r}4.4 \pm 0.6 \\
92.0 \pm 2.8\end{array}$ & $\begin{array}{r}2.5 \pm 0.7 \\
90.7 \pm 0.7\end{array}$ & $\begin{array}{r}1.8 \pm 0.1 \\
100.0 \pm 0.0\end{array}$ \\
\hline
\end{tabular}

The table shows the percentage of dead cells compared to total cells. After treatment with hydroxysterols, cells were trypsinized and stained with Trypan Blue at each indicated time point. The total number of cells and the number of stained cells were counted. Data are mean $\pm S$.E. of at least three independent experiments 

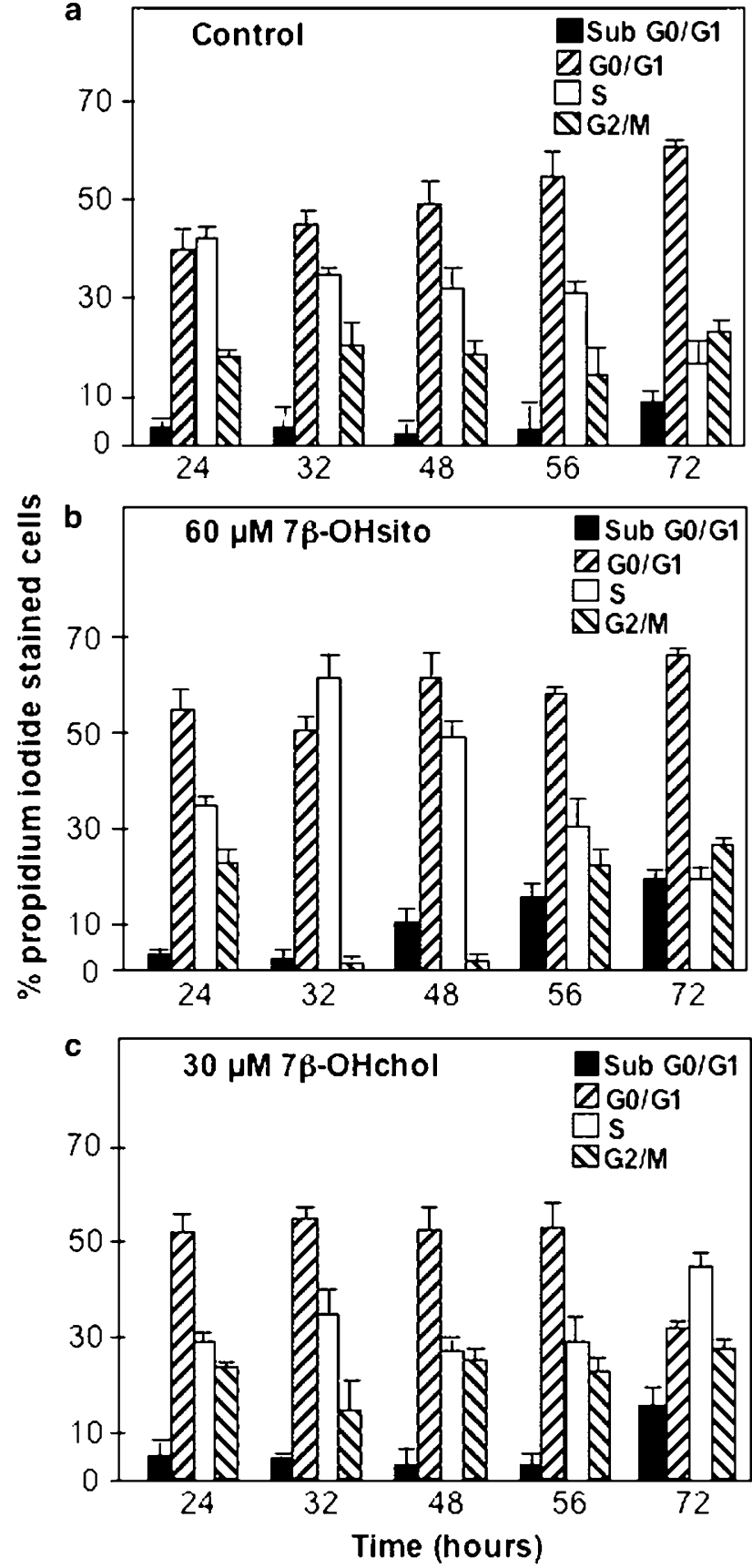

Figure $27 \beta$-OHsito and $7 \beta$-OHchol effects on cell cycle. Cell cycle phases were analyzed for $72 \mathrm{~h}$. Cells were treated with ethanol $(0.5 \%), 7 \beta$-OHsito $(60 \mu \mathrm{M})$ and $7 \beta-\mathrm{OHchol}(30 \mu \mathrm{M})$. At each indicated time point, cells were harvested, stained with $\mathrm{PI}$ and submitted to flow cytometry analysis. Results are presented as the percentage of labelled cells at each cell cycle phase. Data are presented as the mean \pm S.E. of at least three separate experiments

\section{Detection of DNA fragmentation induced by $7 \beta$-OHsito and $7 \beta$-OHchol treatment}

Apoptosis was also evaluated by determination of DNA fragmentation. ${ }^{45}$ DNA integrity was evaluated by gel electrophoresis (Figure 5). In the presence of $7 \beta$-OHsito, DNA

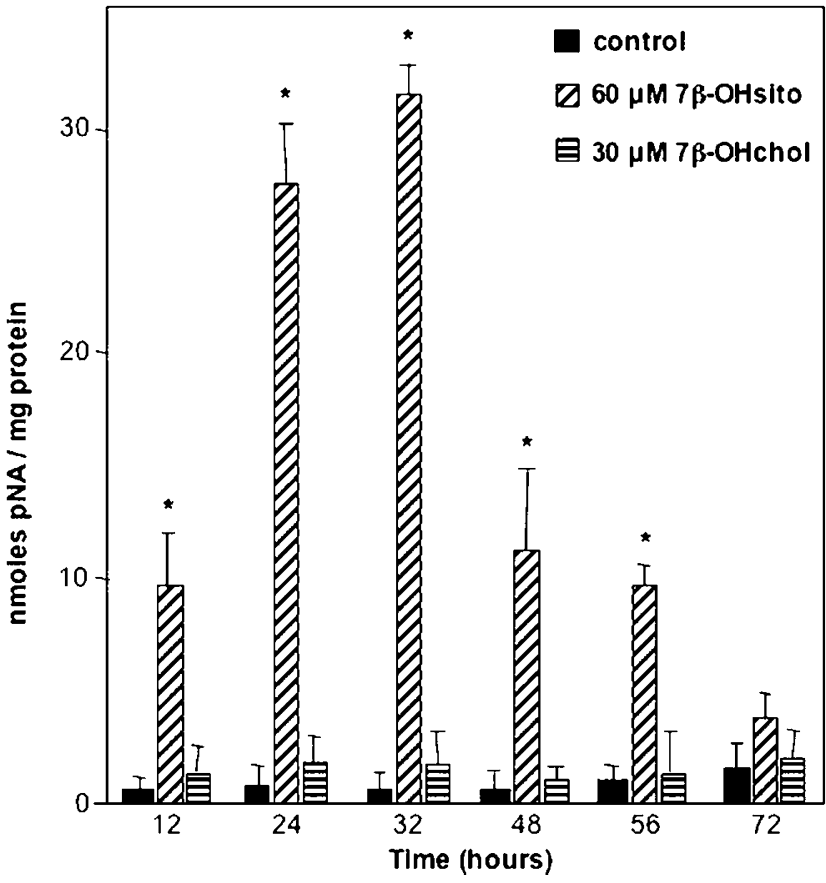

Figure 3 Effect of hydroxysterols on caspase-3 activity. Caco-2 cells were exposed to $0.5 \%$ ethanol (control), to $60 \mu \mathrm{M} 7 \beta$-OHsito or to $30 \mu \mathrm{M} 7 \beta$-OHcho for $72 \mathrm{~h}$. Results are indicated as nmol of pNA released/mg of total protein. Data are presented as the mean \pm S.E. of at least three separate experiments. The asterisk indicates a significant difference between controls and treated $(P<0.05)$

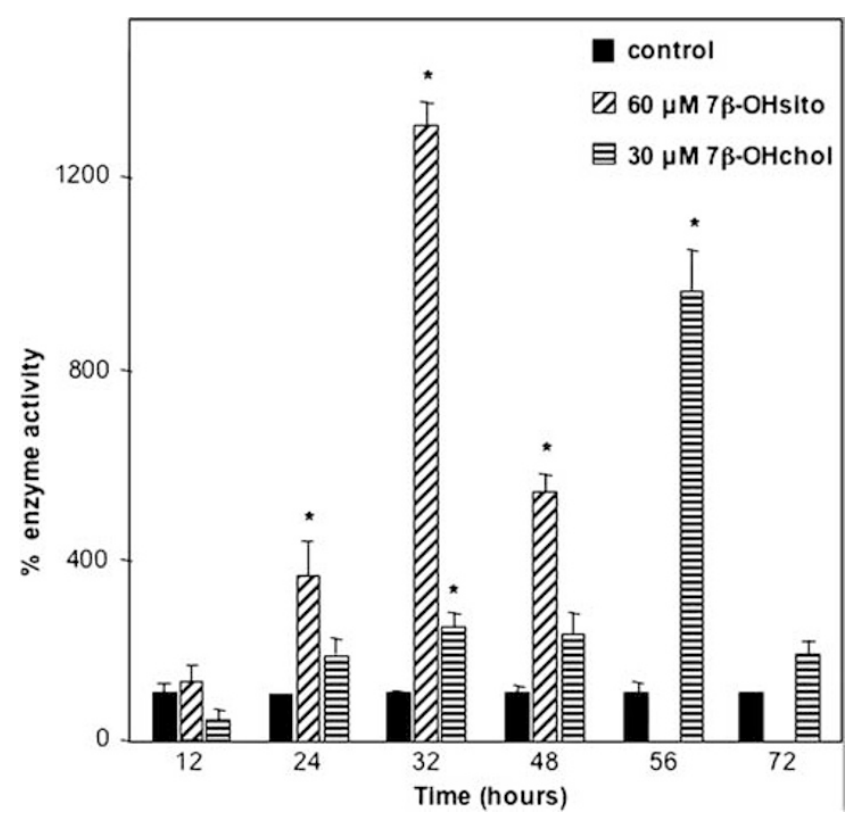

Figure 4 Effect of hydroxysterols on caspase-9 activity. Caco-2 cells were exposed to $0.5 \%$ ethanol (control) or to $60 \mu \mathrm{M} 7 \beta$-OHsito or to $30 \mu \mathrm{M} 7 \beta$-OHchol. At each time point, cells were isolated and prepared for measurement of caspase-9 activities. Values were adjusted to total cell protein and results are presented as the percent of caspase- 9 activity. The basic level was considered at $100 \%$ (nontreated control cells). All data are represented as the mean + S.E. of at least three separate experiments. The asterisk indicates a significant difference between controls and treated $(P<0.05)$ 
fragmentation was detected already after $56 \mathrm{~h}$ of treatment, but DNA fragmentation was delayed in cells treated with $7 \beta$-OHchol and appeared only after $72 \mathrm{~h}$.

\section{Effect of pancaspase inhibitor Z-VAD.fmk on $7 \beta$-OHsito- and $7 \beta$-OHchol- treated cells}

To determine whether cell death occurs independent of caspase- 3 and -9 activities, Caco- 2 cells were treated with the pancaspase inhibitor Z-VAD.fmk before treatment with hydroxysterols.

As illustrated in Figure 6, for cells treated with $7 \beta$-OHsito, cell death was retarded in the presence of Z-VAD.fmk. In contrast, the caspase inhibitor showed no significant effects on untreated cells or on cells treated with $7 \beta-\mathrm{OHchol}$. This suggests that caspase-mediated death pathways are involved in the case of $7 \beta$-Ohsito, whereas other death pathways seem to be involved with $7 \beta-\mathrm{OHchol}$

\section{Discussion}

This study presents new findings on the antiproliferative mechanism of $7 \beta$-OHsito versus $7 \beta$-OHchol on human colon cancer cells. Caco- 2 cells are more sensitive to $7 \beta$-OHchol than to $7 \beta$-OHsito. These compounds caused the same death rate if used at 30 and $60 \mu \mathrm{M}$, respectively.

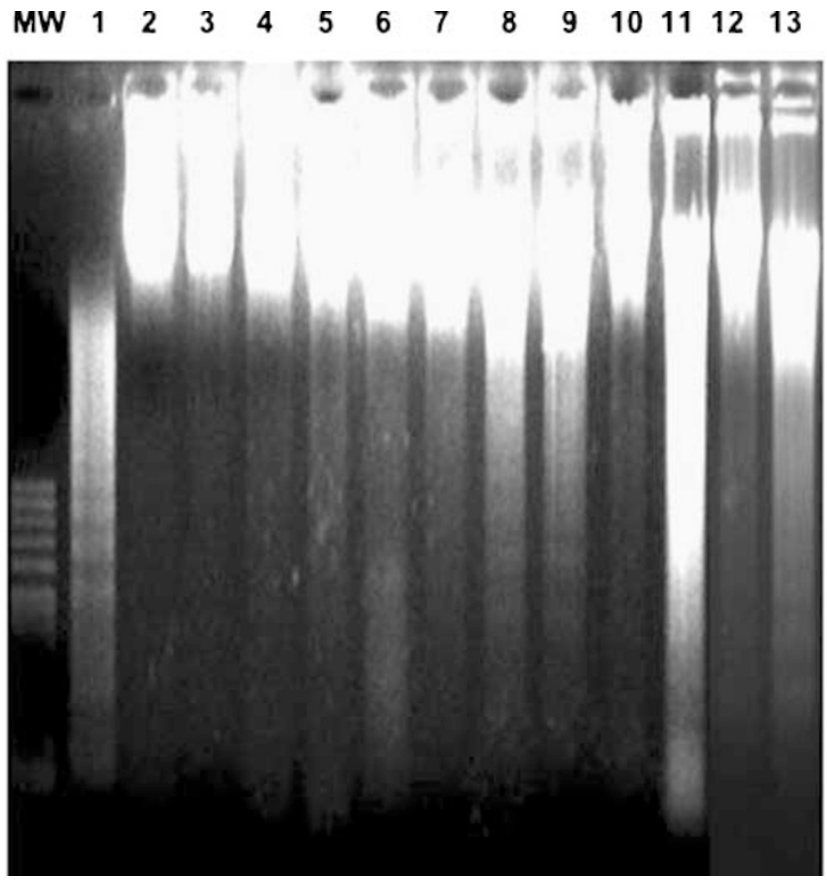

Figure 5 Effect of hydroxysterols on DNA fragmentation. Caco-2 cells were treated with $0.5 \%$ ethanol or with $60 \mu \mathrm{M} 7 \beta-\mathrm{OHsito}$ or $30 \mu \mathrm{M} 7 \beta-\mathrm{OH}$ chol. At different time points, cells were harvested and lysed. Fragmented DNA was separated from genomic DNA by electrophoresis on agarose gel. MW, molecular weight marker; 1 , positive control; controls: 2 , at $32 \mathrm{~h} ; 3$, at $48 \mathrm{~h} ; 4$, at $56 \mathrm{~h} ; 5$, at $72 \mathrm{~h} ; 60 \mu \mathrm{M} 7 \beta$-OHsito: 6 , at $32 \mathrm{~h} ; 7$, at $48 \mathrm{~h} ; 8$, at $56 \mathrm{~h} ; 9$, at $72 \mathrm{~h} ; 30 \mu \mathrm{M}$ $7 \beta$-OHchol: 10 , at $32 \mathrm{~h} ; 11$, at $48 \mathrm{~h} ; 12$, at $56 \mathrm{~h} ; 13$, at $72 \mathrm{~h}$. Note that DNA fragmentation was observed only for $60 \mu \mathrm{M} 7 \beta$-OHsito at $56 \mathrm{~h}(8)$ and $72 \mathrm{~h}(9)$ and for $30 \mu \mathrm{M} 7 \beta-\mathrm{OHchol}$ at $72 \mathrm{~h}(13)$
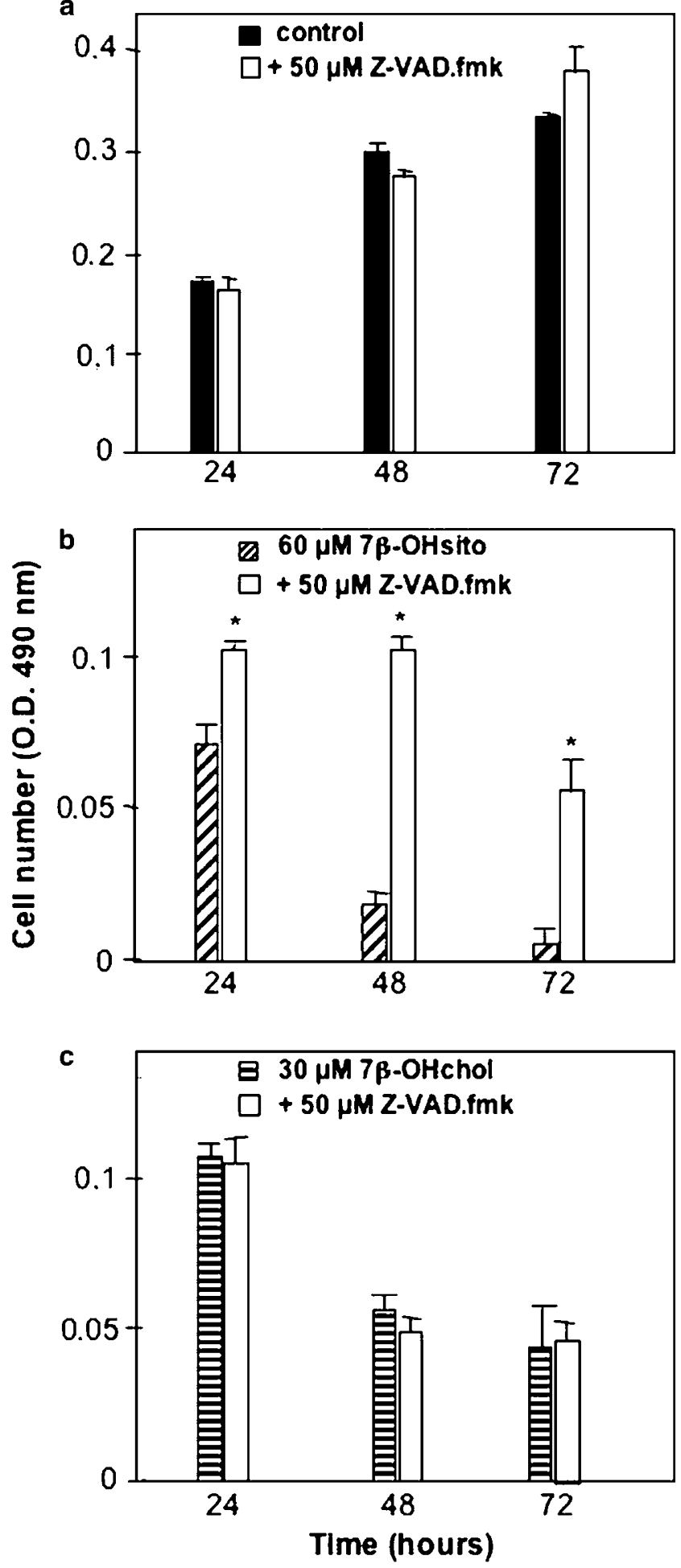

Figure 6 Effect of pancaspase inhibitor Z-VAD.fmk on $7 \beta$-OHsito- and $7 \beta$-OHchol-treated cells. Subconfluent Caco-2 cells were treated with $0.5 \%$ ethanol or $60 \mu \mathrm{M} 7 \beta$-OHsito or $30 \mu \mathrm{M} 7 \beta$-OHchol in the presence or absence of $50 \mu \mathrm{M}$ Z-VAD.fmk for $96 \mathrm{~h}$. The medium was changed every $24 \mathrm{~h}$. Cell growth was measured in the presence or absence of $7 \beta$-OHsito $60 \mu \mathrm{M}$ and $7 \beta$-OHchol $30 \mu \mathrm{M}$. Data are presented as the mean + S.E. of at least three separate experiments. The asterisk indicates a significant difference between controls and treated $(P<0.05)$ 
Only $7 \beta$-OHsito altered cell cycle traverse leading to an accumulation in $S$ phase, and a simultaneous decrease of cells engaged in the G2/M phase. In parallel, cells underwent apoptosis as characterized by the accumulation of cells containing hypodiploid DNA. ${ }^{42,43}$ In contrast, $7 \beta$-OHchol did not alter the cell cycle, and delayed apoptosis by several hours. On the one hand, $7 \beta-\mathrm{OH}$ sito induced an apoptotic process mediated by caspase- 9 and -3 activation, and on the other, cells treated with $7 \beta$-OHchol never showed activation of caspase-3, and only a low activation of caspase-9. However, DNA fragmentation was similarly enhanced in cells treated with both hydroxysterols. By using the broad-spectrum caspase inhibitor Z-VAD.fmk, ${ }^{31,46,47}$ we demonstrated that caspases activation plays an important role in the antiproliferative effect initiated by $7 \beta-\mathrm{OH}$ sito. This was not the case for cells treated with $7 \beta$-OHchol, which were not affected by the caspase inhibitor. These results indicate that different apoptotic processes are involved in the antiproliferative effects of the two compounds.

Another study has shown that both compounds exhibited a similar cytotoxicity pattern in U937 cells, whereas hydroxyphytosterols were less toxic. ${ }^{24}$ Cholesterol oxides and a mixture of $\beta$-sitosterol/campesterol oxides were examined for their cytotoxic effects on a macrophage-derived cell line (C57BL/6). All compounds exhibited similar cytotoxicity as indicated by LDH leakage, cell viability and mitochondria dehydrogenase activity, although oxyphytosterols exerted less severe effects than cholesterol oxides. ${ }^{23}$

In the presence of the pancaspase inhibitor, Z-VAD.fmk, apoptotic events were not completely suppressed. ${ }^{31}$ Hence, $7 \beta$-OHsito may trigger apoptosis through postmitochondrial caspase cascades and DNA fragmentation. ${ }^{48,49}$ In contrast, $7 \beta$-OHchol showed no effect on cell cycle and induced cell death mechanisms leading to DNA fragmentation that were not delayed by the inhibitor Z-VAD.fmk. During the treatment with $7 \beta$-OHchol, a low but significant level of caspase-9 activity was measured, which did not induce an apoptotic process involving the activation of caspase-3. It was recently reported that when U937 leukemia cells were exposed to $7 \beta$ $\mathrm{OHchol}$, they showed apoptotic characteristics such as permeability to $\mathrm{PI}$, condensed and/or fragmented nuclei. It was suggested that these cells were apoptotic but that a different cell death pathway controlled by autophagic process was induced. ${ }^{38}$ It is possible that autophagy delays apoptosis, as was described for HT-29 cells treated with sulindac sulfide $^{50}$ It is worth noting that these events are not to be considered necessarily as separate events. ${ }^{51}$

Cholesterol oxides are potent regulators of cholesterol metabolism. ${ }^{52}$ They can enter in cells directly and are recognized by the oxysterol binding protein (OBP) localized in the endoplasmic reticulum ${ }^{37,53}$ or by other OBPs such as liver $X$ receptor. ${ }^{54,55}$ This interaction may lead to the regulation of sterol metabolism by transcriptional responses. $^{37}$ In this case, HMG-CoA reductase may be inhibited leading to the inhibition of cholesterol synthesis, with the consequence that cholesterol availability will be limited for cell growth and cells might undergo cell death. In addition to the antiproliferative properties of cholesterol oxides, it is known that these compounds are able to induce oxidative stress and consequently, they can play a direct role in atherogenesis or induce apoptosis of cancer cells. ${ }^{30,56,57}$ Oxidative stress induced by hydroxylated plant sterols and related products was not described.

At a first glance, it is difficult to explain why we observed caspase- 9 activation and DNA fragmentation with $7 \beta$-OHchol, without any activation of caspase-3. However, it was previously shown that other inhibitors of HMG-CoA reductase, such as lovastatin, induce apoptosis in various cell types in which the role of caspase-3 is also controversial. ${ }^{58,59}$ Caspase-independent cell death might be mediated by apoptosis-inducing factor (AIF), a mitochondrial flavoprotein, which is translocated from the mitochondria to the cytosol and to the nucleus when apoptosis has started. AIF has multiple effects such as activation of endonucleases, and phosphatidyl serine exposure at the cell surface. It also induces cytochrome $c$ release, ${ }^{60-62}$ which may explain the delayed caspase- 9 activation observed with $7 \beta$-OHchol in our present study.

Concerning $7 \beta$-OHsito, no data are available for its action at the cell surface. This $\beta$-sitosterol derivative acts as a cholesterol-lowering agent by inhibiting cholesterol absorption through displacement of cholesterol from micelles, but not by inhibiting cholesterol synthesis. In fact, inhibition of cholesterol absorption favors intracellular cholesterol synthesis without any negative effect on HMG-CoA reductase activity. ${ }^{63}$ It can be assumed that the additional alkyl group in the side chain prevents the plant sterols from an interaction with the sites responsible for the feedback regulation of cholesterol synthesis. ${ }^{64}$ It is known that the alkyl side chain render plant sterols more hydrophobic and consequently, they pass through the cell membrane more easily and provoke excitability inducing membrane-bound or intracellular enzymes. ${ }^{13,19}$

In summary, the effects of $7 \beta-\mathrm{OH}$ sito and $7 \beta$-OHchol both induce death of Caco-2 cells. However, the two compounds target different death pathways in spite of their structural similarity. In the case of $7 \beta$-OHsito, the intracellular caspase cascade is activated, whereas in the case of $7 \beta-\mathrm{OHchol}$, the process is more complex and may involve various caspaseindependent factors, including cholesterol metabolism and its products, oxidative stress compounds and/or autophagic processes. These differences may be of interest for the development of new anticancer strategies.

\section{Materials and Methods}

\section{Cell culture}

Human colon adenocarcinoma Caco-2 cells were purchased from the European Collection of Animal Cell Culture (ECACC Salisbury, UK). They were cultured in $75 \mathrm{~cm}^{2}$ Falcon flasks in Dulbecco's modified Eagle's medium (DMEM) containing $25 \mathrm{mM}$ glucose and supplemented with $10 \%$ heat-inactivated $\left(56^{\circ} \mathrm{C}\right)$ horse serum, $100 \mathrm{U} / \mathrm{ml}$ penicillin, $100 \mu \mathrm{g} / \mathrm{ml}$ streptomycin, $1 \%$ nonessential amino acids (Gibco, Invitrogen Corp., Cergy Pontoise, France). Cells were incubated at $37^{\circ} \mathrm{C}$ in a humidified atmosphere with $5 \% \quad \mathrm{CO}_{2}$ and subcultured to preconfluency after trypsinization (0.5\% trypsin/2.6 mM EDTA).

For all experiments, cells were seeded at $1 \times 10^{4}$ cells/well in 96-well plates and $1 \times 10^{6}$ cells in culture dishes $(10 \mathrm{~mm}$ diameter). The culture medium was DMEM supplemented with $3 \%$ heat-inactivated horse serum, $5 \mu \mathrm{g} / \mathrm{ml}$ transferrin, $5 \mathrm{ng} / \mathrm{ml}$ selenium and $10 \mu \mathrm{g} / \mathrm{ml}$ insulin (Gibco, France). 


\section{Cell culture treatments with $7 \beta-\mathrm{OHsito}, 7 \beta-\mathrm{OH}$ chol and pancaspase inhibitor Z-VAD.fmk}

Cells were treated with $7 \beta-\mathrm{OH}$ sito and $7 \beta-\mathrm{OH}$ chol at 30 and $60 \mu \mathrm{M}$. The $\beta$-sitosterol was purified by preparative adsorption chromatography starting from a commercial mixture of phytosterols (unsaponifiable fraction of Soya oil). The purity of the obtained $\beta$-sitosterol was higher than $95 \%$. The impurities consisted of traces of campesterol. Cholesterol was a Sigma product (Sigma-Aldrich, Steinheim, Germany). The $\beta$-sitosterol and cholesterol were oxidized according to the method suggested by Schroepfer et al. ${ }^{65}$ After purification on silica column, the $7 \beta-\mathrm{OH}$ sito and $7 \beta$-OHchol were obtained with purities of about $95 \%$. Ethanol $0.5 \%(\mathrm{v} / \mathrm{v})$ was used for control group and as solvent for sterols. Untreated and treated cells were exposed to $50 \mu \mathrm{M}$ of Z-VAD.fmk (in $0.1 \%$ dimethyl sulfoxide (DMSO)), (Sigma-Aldrich, Germany) for $1 \mathrm{~h}$ prior to exposure to sterols. Control cells were treated with both $0.5 \%$ ethanol and $0.1 \%$ DMSO. In all experiments, cells were incubated in a humidified atmosphere $\left(5 \% \mathrm{CO}_{2}\right.$ at $\left.37^{\circ} \mathrm{C}\right)$ for $1-8$ days. Culture medium was changed every $24 \mathrm{~h}$ or $48 \mathrm{~h}$.

\section{Cell growth}

Cells $\left(1 \times 10^{4} /\right.$ well) were seeded in 96-well plates. Cells were exposed to different compounds $24 \mathrm{~h}$ after seeding and incubated for different times. Cell culture was stopped by the addition of $50 \mu \mathrm{l}$ trichloroacetic acid $(50 \%$, $\mathrm{v} / \mathrm{v})$ and cell proteins were stained with $200 \mu \mathrm{ISRB}(0.4 \%(\mathrm{w} / \mathrm{v}))$ diluted in $1 \%$ acetic acid (Sigma-Aldrich, Germany). Cells were rinsed three times with $1 \%$ acid acetic. A measure of $200 \mu \mathrm{l} /$ well of $10 \mathrm{mM}$ Tris- $\mathrm{HCl}(\mathrm{pH} 10.5)$ was added and absorbance was measured at $490 \mathrm{~nm}$. The relationship between cell number (protein content/well) and absorbance is linear from 0 to $200000 \mathrm{cells} /$ well. For estimation of cell survival, cells were stained with Trypan Blue Dye (Gibco, France) (1/1, v/v) and the number of stained and nonstained cells was determined by optical microscopy.

\section{Cell cycle analysis}

Cell cycle distribution was analyzed by labeling cells with $\mathrm{PI}$ and assays were carried out as described previously. ${ }^{43}$ Briefly, $1 \times 10^{6}$ cells were seeded in $10 \mathrm{~mm}$ plates and harvested by trypsinization (0.5\% trypsin $2.6 \mathrm{mM}$ EDTA) at different time points after initial treatment with hydroxysterols. Then, cells were centrifuged and fixed in $1 \mathrm{ml}$ methanol:PBS $(9: 1, v / v)$, washed twice in PBS and resuspended in $200 \mu \mathrm{l}$ PBS containing $0.25 \mathrm{mg} / \mathrm{ml}$ RNAse A and $0.1 \mathrm{mg} / \mathrm{ml} \mathrm{PI} \mathrm{(Sigma-}$ Aldrich, Germany). After incubation in the dark at $37^{\circ} \mathrm{C}$ for $30 \mathrm{~min}$, the fluorescence of 10000 cells was analyzed using a FACSCcan flow cytometer and CellQuest software (Becton Dickinson, San Jose, CA, USA).

\section{Determination of caspase-3, -8 and -9 activities}

Cells $\left(1 \times 10^{6}\right)$ were harvested, washed twice in PBS and stored at $-20^{\circ} \mathrm{C}$. Caspase- 3 and -8 activity was detected by using Caspase- 3 and Caspase-8 Assay Colorimetric Kits (Sigma-Aldrich, Germany). These assays were based on the hydrolysis of the peptide substrate Ac-DEVDpNA by caspase-3 and of the peptide substrate Ac-IETD-pNA by caspase8 , resulting in the release of a pNA moiety. The concentration of the pNA released was calculated from the absorbance values at $405 \mathrm{~nm}$ and calibration curve of defined pNA solutions. Results were adjusted to the total protein content, and values were expressed as nmol pNA/mg of total protein.
For caspase-9 activity measurement, the Caspase-9 Colorimetric Assay (R\&D Systems, Minneapolis, USA) was used. This assay was similar to the procedure described above, except for the peptide substrate, which was LEHD-pNA. Results were expressed as fold increase in caspase activity of apoptotic cells over that of noninduced cells.

\section{Determination of DNA fragmentation}

Detection of apoptotic DNA from high molecular weight, intact, genomic DNA was performed as described previously. ${ }^{66}$ In brief, $1 \times 10^{6}$ were seeded in $10 \mathrm{~mm}$ plates, treated with hydroxysterols or ethanol and at each time point, cells were collected by trypsinization and centrifugation, and then stored at $-80^{\circ} \mathrm{C}$. Apoptotic DNA was recovered from cells by using the Suicide Track $^{\mathrm{TM}}$ DNA ladder kit (Oncogene Research Products, Cambridge, UK). The samples were loaded into a 1.5\% (w/v) agarose gel containing ethidium bromide and prepared in standard Tris-acetate-EDTA $(\mathrm{pH} 8.5)(50 \times)$ diluted $1 \times$. DNA fragments were separated by electrophoresis $(100 \mathrm{~V}, 30 \mathrm{~min})$ and were monitored under UV light by transluminator Gel Doc 2000 and analyzed with Quantity One 1-D Analysis Software (BioRad Laboratories, Marnes-la-Coquette, France).

\section{Statistical analysis}

All experiments were performed at least three times. Data are reported as mean \pm S.E. Statistical differences between control group and treated cells were evaluated using the Student's $t$-test. Differences were considered significant at $P<0.05$.

\section{Acknowledgements}

We are grateful to Dr. Nikolaus Seiler for advice and critical reading of the manuscript. This work was supported by a grant from the Ministère de la Jeunesse, de l'Education Nationale et de la Recherche, France (RARE 015 No. 02 P 0641).

\section{References}

1. Tapiero H, Townsend DM and Tew KD (2003) Phytosterols in the prevention of human pathologies. Biomed. Pharmacother. 57: 321-325

2. Igel M, Giesa U, Lutjohann D and von Bergmann K (2003) Comparison of the intestinal uptake of cholesterol, plant sterols, and stanols in mice. J. Lipid Res. 44: $533-538$

3. Christiansen LI, Lahteenmaki PL, Mannelin MR, Seppanen-Laakso TE, Hiltunen RV and Yliruusi JK (2001) Cholesterol-lowering effect of spreads enriched with microcrystalline plant sterols in hypercholesterolemic subjects. Eur. J. Nutr. 40: 66-73

4. Miettinen TA and Gylling $\mathrm{H}$ (2003) Non-nutritive bioactive constituents of plants: phytosterols. Int. J. Vitam. Nutr. Res. 73: 127-134

5. De Jong A, Plat J and Mensink RP (2003) Metabolic effects of plant sterols and stanols. J. Nutr. Biochem. 14: 362-369

6. Plat J, Kerckhoffs DA and Mensink RP (2000) Therapeutic potential of plant sterols and stanols. Curr. Opin. Lipidol. 11: 571-576

7. Clifton PM, Noakes M, Sullivan D, Erichsen N, Ross D, Annison G, Fassoulakis $A$, Cehun $M$ and Nestel $P$ (2004) Cholesterol-lowering effects of plant sterol esters differ in milk, yoghurt, bread and cereal. Eur. J. Clin. Nutr. 58: 503-509

8. Ostlund Jr RE, Racette SB and Stenson WF (2002) Effects of trace components of dietary fat on cholesterol metabolism: phytosterols, oxysterols, and squalene. Nutr. Rev. 60: 349-359

9. Plat $\mathrm{J}$ and Mnsink PP (2001) Effects of plant sterols and stanols on lipid metabolism and cardiovascular risk. Nutr. Metab. Cardiovasc. Dis. 11: 31-40 
10. Kozlowska-Wojciechowska M, Jastrzebska M, Naruszewicz M and Foltynska A (2003) Impact of margarine enriched with plant sterols on blood lipids, platelet function, and fibrinogen level in young men. Metabolism 52: 1373-1378

11. Moghadasian MH (2000) Pharmacological properties of plant sterols in vivo and in vitro observations. Life Sci. 67: 605-615

12. Normen AL, Brants HA, Voorrips LE, Andersson HA, van den Brandt PA and Goldbohm RA (2001) Plant sterol intakes and colorectal cancer risk in the Netherlands Cohort Study on Diet and Cancer. Am. J. Clin. Nutr. 74: 141-148

13. Awad AB and Fink CS (2000) Phytosterols as anticancer dietary components: evidence and mechanism of action. J. Nutr. 130: 2127-2130

14. Fahy DM, O'Callaghan YC and O'Brien NM (2004) Phytosterols: lack of cytotoxicity but interference with beta-carotene uptake in Caco-2 cells in culture. Food Addit. Contam. 21: 42-51

15. Awad AB, Roy R and Fink CS (2003) Beta-sitosterol, a plant sterol, induces apoptosis and activates key caspases in MDA-MB-231 human breast cancer cells. Oncol. Rep. 10: 497-500

16. Awad AB, Downie AC and Fink CS (2000) Inhibition of growth and stimulation of apoptosis by beta-sitosterol treatment of MDA-MB-231 human breast cancer cells in culture. Int. J. Mol. Med. 5: 541-545

17. Awad AB, Fink CS, Williams $\mathrm{H}$ and $\mathrm{Kim} U$ (2001) In vitro and in vivo (SCID mice) effects of phytosterols on the growth and dissemination of human prostate cancer PC-3 cells. Eur. J. Cancer Prev. 10: 507-513

18. Awad AB, von Holtz RL, Cone JP, Fink CS and Chen YC (1998) Beta-sitosterol inhibits growth of HT-29 human colon cancer cells by activating the sphingomyelin cycle. Anticancer Res. 18: 471-473

19. Awad AB, Chen YC, Fink CS and Hennessey T (1996) Beta-sitosterol inhibits $\mathrm{HT}-29$ human colon cancer cell growth and alters membrane lipids. Anticancer Res. 16: 2797-2804

20. Choi YH, Kong KR, Kim YA, Jung KO, Kil JH, Rhee SH and Park KY (2003) Induction of Bax and activation of caspases during beta-sitosterol-mediated apoptosis in human colon cancer cells. Int. J. Oncol. 23: 1657-1662

21. Daly GG, Finocchairo ET and Richardson T (1983) Characterization of some oxidation products of sitosterol. J. Agric. Food Chem. 31: 46-50

22. Lutjohann $D$ (2004) Sterol autoxidation: from phytosterols to oxyphytosterols. Br. J. Nutr. 91: 3-4

23. Adcox C, Boyd L, Oehrl L, Allen J and Fenner G (2001) Comparative effects of phytosterol oxides and cholesterol oxides in cultured macrophage-derived cell lines. J. Agric. Food Chem. 49: 2090-2095

24. Maguire L, Konoplyannikov M, Ford A, Maguire AR and O'Brien NM (2003) Comparison of the cytotoxic effects of beta-sitosterol oxides and a cholesterol oxide, 7beta-hydroxycholesterol, in cultured mammalian cells. Br. J. Nutr. 90: 767-775

25. Witztum JL and Steinberg D (1991) Role of oxidized low density lipoprotein in atherogenesis. J. Clin. Invest. 88: 1785-1792

26. Biasi F, Leonarduzzi G, Vizio B, Zanetti D, Sevanian A, Sottero B, Verde V, Zingaro $B$, Chiarpotto $E$ and Poli $G$ (2004) Oxysterol mixtures prevent proapoptotic effects of 7-ketocholesterol in macrophages: implications for proatherogenic gene modulation. FASEB J. 18: 693-695

27. Lizard G, Monier S, Cordelet C, Gesquiere L, Deckert V, Gueldry S, Lagrost L and Gambert P (1999) Characterization and comparison of the mode of cell death, apoptosis versus necrosis, induced by 7 beta-hydroxycholesterol and 7ketocholesterol in the cells of the vascular wall. Arterioscler. Thromb. Vasc. Biol. 19: 1190-1200

28. Ji YH, Moog C, Schmitt G, Bischoff P and Luu B (1990) Monophosphoric acid diesters of 7 beta-hydroxycholesterol and of pyrimidine nucleosides as potential antitumor agents: synthesis and preliminary evaluation of antitumor activity. J. Med. Chem. 33: 2264-2270

29. Lim HK, Kang HK, Yoo ES, Kim BJ, Kim YW, Cho M, Lee JH, Lee YS, Chung $\mathrm{MH}$ and Hyun JW (2003) Oxysterols induce apoptosis and accumulation of cell cycle at G(2)/M phase in the human monocytic THP-1 cell line. Life Sci. 72: 1389-1399

30. Miguet-Alfonsi C, Prunet C, Monier S, Bessede G, Lemaire-Ewing S, Berthier A, Menetrier F, Neel D, Gambert P and Lizard G (2002) Analysis of oxidative processes and of myelin figures formation before and after the loss of mitochondrial transmembrane potential during 7beta-hydroxycholesterol and 7ketocholesterol-induced apoptosis: comparison with various pro-apoptotic chemicals. Biochem. Pharmacol. 64: 527-541

31. Miguet C, Monier S, Bettaieb A, Athias A, Bessede G, Laubriet A, Lemaire S, Neel D, Gambert $P$ and Lizard $G$ (2001) Ceramide generation occurring during 7beta-hydroxycholesterol- and 7-ketocholesterol-induced apoptosis is caspase independent and is not required to trigger cell death. Cell Death Differ. 8: 83-99

32. Guardiola F, Codony R, Addis PB, Rafecas M and Boatella J (1996) Biological effects of oxysterols: current status. Food Chem. Toxicol. 34: 193-211

33. O'Callaghan YC, Woods JA and O'Brien NM (2002) Characteristics of 7 betahydroxycholesterol-induced cell death in a human monocytic blood cell line, U937, and a human hepatoma cell line, HepG2. Toxicol. In Vitro 16: 245-251

34. Schroepfer Jr GJ (2000) Oxysterols: modulators of cholesterol metabolism and other processes. Physiol. Rev. 80: 361-554

35. Theunissen JJ, Jackson RL, Kempen HJ and Demel RA (1986) Membrane properties of oxysterols. Interfacial orientation, influence on membrane permeability and redistribution between membranes. Biochim. Biophys. Acta 860: $66-74$

36. Thompson EB and Ayala-Torres S (1999) Oxysterols and apoptosis: evidence for gene regulation outside the cholesterol pathway. Crit. Rev. Biochem. Mol. Biol. 34: 25-32

37. Olkkonen VM and Levine TP (2004) Oxysterol binding proteins: in more than one place at one time? Biochem. Cell Biol. 82: 87-98

38. Monier S, Samadi M, Prunet C, Denance M, Laubriet A, Athias A, Berthier A, Steinmetz E, Jurgens G, Negre-Salvayre A, Bessede G, Lemaire-Ewing S, Neel D, Gambert P and Lizard G (2003) Impairment of the cytotoxic and oxidative activities of 7 beta-hydroxycholesterol and 7-ketocholesterol by esterification with oleate. Biochem. Biophys. Res. Commun. 303: 814-824

39. Maier G, Bing G, Falken U, Wagner E and Unger C (1999) Antitumor activity and induction of apoptosis by water-soluble derivatives of 7 betahydroxycholesterol in human colon carcinoma cell lines. Anticancer Res. 19: 4251-4256

40. Clifton P (2002) Plant sterol and stanols - comparison and contrasts. Sterols versus stanols in cholesterol-lowering: is there a difference? Atheroscler. Suppl. 3: 5-9

41. Skehan P, Storeng R, Scudiero D, Monks A, McMahon J, Vistica D, Warren JT, Bokesch H, Kenney S and Boyd MR (1990) New colorimetric cytotoxicity assay for anticancer-drug screening. J. Natl. Cancer Inst. 82: 1107-1112

42. Darzynkiewicz Z, Bruno S, Del Bino G, Gorczyca W, Hotz MA, Lassota P and Traganos $F$ (1992) Features of apoptotic cells measured by flow cytometry. Cytometry 13: 795-808

43. Nicoletti I, Migliorati G, Pagliacci MC, Grignani F and Riccardi C (1991) A rapid and simple method for measuring thymocyte apoptosis by propidium iodide staining and flow cytometry. J. Immunol. Methods 139: 271-279

44. Gurtu V, Kain SR and Zhang G. (1997) Fluorometric and colorimetric detection of caspase activity associated with apoptosis. Anal. Biochem. 251: 98-102

45. Matassov D, Kagan T, Leblanc J, Sikorska M and Zakeri Z (2004) Measurement of apoptosis by DNA fragmentation. Methods Mol. Biol. 282: 1-18

46. Rabkin SW and Kong JY (2003) Lovastatin-induced cardiac toxicity involves both oncotic and apoptotic cell death with the apoptotic component blunted by both caspase-2 and caspase-3 inhibitors. Toxicol. Appl. Pharmacol. 193: 346-355

47. Cummings BS, Kinsey GR, Bolchoz LJ and Schnellmann RG (2004) Identification of caspase-independent apoptosis in epithelial and cancer cells. J. Pharmacol. Exp. Ther. 310: 126-134

48. Herr I and Debatin KM (2001) Cellular stress response and apoptosis in cancer therapy. Blood 98: 2603-2614

49. Hengartner MO (2000) The biochemistry of apoptosis. Nature 407: 770-776

50. Bauvy C, Gane P, Arico S, Codogno P and Ogier-Denis E (2001) Autophagy delays sulindac sulfide-induced apoptosis in the human intestinal colon cancer cell line HT-29. Exp. Cell Res. 268: 139-149

51. Bursch W, Ellinger A, Gerner C, Frohwein U and Schulte-Hermann R (2000) Programmed cell death (PCD). Apoptosis, autophagic PCD, or others? Ann. NY Acad. Sci. 926: 1-12

52. Kandutsch AA and Chen HW (1973) Inhibition of sterol synthesis in cultured mouse cells by 7alpha-hydroxycholesterol, 7beta-hydroxycholesterol, and 7ketocholesterol. J. Biol. Chem. 248: 8408-8417

53. Luu B and Moog C (1991) Oxysterols: biological activities and physicochemical studies. Biochimie 73: 1317-1320

54. Peet DJ, Janowski BA and Mangelsdorf DJ (1998) The LXRs: a new class of oxysterol receptors. Curr. Opin. Genet. Dev. 8: 571-575

55. Taylor FR, Saucier SE, Shown EP, Parish EJ and Kandutsch AA (1984) Correlation between oxysterol binding to a cytosolic binding protein and 
potency in the repression of hydroxymethylglutaryl coenzyme A reductase. J. Biol. Chem. 259: 12382-12387

56. Adachi J, Fujita T, Kudo R, Asano M, Nurhantari Y and Ueno Y (2003) 7hydroperoxycholesterol and oxysterols as indices of oxidative stress: chronic ethanol feeding and rat skeletal muscle. Leg. Med. (Tokyo) 1: 105-109

57. Ryan L, O'Callaghan YC and O'Brien NM (2004) Generation of an oxidative stress precedes caspase activation during 7beta-hydroxycholesterol-induced apoptosis in U937 cells. J. Biochem. Mol. Toxicol. 18: 50-59

58. limura O, Vrtovsnik F, Terzi F and Friedlander G (1997) HMG-CoA reductase inhibitors induce apoptosis in mouse proximal tubular cells in primary culture. Kidney Int. 52: 962-972

59. Rabkin SW and Kong JY (2003) Lovastatin-induced cardiac toxicity involves both oncotic and apoptotic cell death with the apoptotic component blunted by both caspase-2 and caspase-3 inhibitors. Toxicol. Appl. Pharmacol. 193: 346-355

60. Cregan SP, Dawson VL and Slack RS (2004) Role of AIF in caspasedependent and caspase-independent cell death. Oncogene 23: 2785-2796
61. Tsujimoto $Y(2003)$ Cell death regulation by the Bcl-2 protein family in the mitochondria. J. Cell. Physiol. 195: 158-167

62. Lockshin RA and Zakeri Z (2004) Caspase-independent cell death? Oncogene 23: $2766-2773$

63. Berger A, Jones PJ and Abumweis SS (2004) Plant sterols: factors affecting their efficacy and safety as functional food ingredients. Lipids Health Dis. 3 : 5-12

64. Kakis G and Kuksis A (1984) Effect of intravenous infusion of intralipid, cholesterol, and plant sterols on hepatic cholesterogenesis. Can. J. Biochem. Cell Biol. 62: 1-10

65. Li S, Pang J, Wilson W K and Schroepfer Jr GJ (1999) Sterol synthesis. Preparation and characterization of fluorinated and deuterated analogs of oxygenated derivatives of cholesterol. Chem. Phys. Lipids 99: 33-71

66. Schneider Y, Chabert P, Stutzmann J, Coelho D, Fougerousse A, Gosse F, Launay JF, Brouillard R and Raul F (2003) Resveratrol analog (Z)-3,5,4'trimethoxystilbene is a potent anti-mitotic drug inhibiting tubulin polymerization. Int. J. Cancer 107: 189-196 